\title{
The important of Ontology to Public Administration
}

\author{
John Gabriel Mendie \\ Research Scholar, AKSU, Akwa Ibom State. \\ E-mail: jgmendie@gmail.com
}

(Received: March-2020; Reviewed: March-2020; Accepted: March-2020;

Avalaibel Online: March-2020; Published: March-2020)

This is an open access article distributed under the Creative Commons Attribution License

CC-BY-NC-4.0 @2020 by author (https://creativecommons.org/licenses/by-nc/4.0/)

\begin{abstract}
Metaphysics, as we understand, is a philosophical enterprise that deals with the nature of the ultimate reality. However, this is a sweeping conception; we can say metaphysics, is concerned with the nature of reality as well as problems of existence which is more appropriately considered under ontological discussions. Thus, there have been questions on whether ontology has vital importance in human practical dealings. This paper aims to show the importance of ontology in administration. The work analysis some existing philosophers' postulation on the importance of ontology in public administration. This work agrees with most philosophers on the ontological abstract theories that have some bearing on the ethical and practical issues. It defends this position by analysing unique cases of humane administration; that metaphysical thesis, theories, and conceptions are equally important in resolving real-life cases. The research is carried out with the philosophical method of textual analysis.
\end{abstract}

Keywords: Metaphysics; Ontology; Public Administration; Practical Issues.

\section{INTRODUCTION}

Achille C. Varzi writes, in On Doing Ontology without Metaphysics, According to Quine, ontology is concerned with the question of what entities exist (a task that is often identified with that of drafting a complete inventory of the universe) whereas metaphysics seeks to explain, of those entities, what they are (that is, to specify the ultimate nature of the items included in the inventory). Katherine Hawley says that core metaphysics should ensue on its own terms, endeavouring to ascertain profound truths about reality, which can be applied to more specific cases regarding ethics, and so on. Thus, metaphysicians 'work is to generate a collection of conceptual tools, relations, and ideas, which can act as a toolbox or set of resources from which other philosophers can pick what works finest for them'. (2017:168).

It seems as philosophy provides us tools in the same way science does which can be applied when needed to solve any practical problem. How we do that is a different issue. The first and foremost question which comes to our mind is whether or not philosophy (here metaphysics), can really be applied over practical issues related to our daily lives? And do they really work to resolve those issues? Answers are in the positive. Thinkers have worked on it and admitted that metaphysical, epistemological, and ethical theories can be used as tool to fix the 
problems existing in our life. This is called toolbox idea. They say that it is just like science. We may use them as a tool to resolve our practical problems. French and McKenzie have developed this toolbox idea on the relationship between metaphysics and philosophy of science. (2012: 4259)

Katherine Hawley accepts that metaphysicians offer us not a solitary and ultimate judgment about our world and reality but entirely diverse and new world outlooks than others, but still it has an impact beyond philosophy. In her own words: brief survey of metaphysics that can be applied within philosophy gives us a starting point for considering some ways in which metaphysics can be applied beyond philosophy (2017: 168). Metaphysics plays an important role in applied ethics, aesthetics, philosophy of religion, art, science, culture, mind and so on. Applied metaphysics is about some specific cases existing within these subject matters and which are impacted by metaphysical conceptions. My attempt, here, is to defend this view that applied metaphysics is important to Administration.

\section{The Sceptics}

It remains a vital question whether applied metaphysics really affects our ways of lives? Opponents refute a possibility of applying metaphysical theories and conceptions in resolving real life imbroglios. Logical positivists and a number of thinkers have been critical towards the very idea of possibility of applied metaphysics. They hold that the noted metaphysical theories about reality have anything to do with resolving the problems which infest our daily life and encounter with the world we live in. Hence, a group of thinkers were antagonistic to the very idea of applying metaphysical theory beyond philosophy (Albahari 2019). However, one thing is for sure that even those antagonistic to the application of metaphysics accept at least obliquely that metaphysics make much sense. It is exactly at this point that the protagonists argue in favour of a possibility of application of standard metaphysical theories in extra-philosophical domain such as psychiatry, cognitive and behavioural science, social and political affairs, and the one I would prefer to consider at length here, is the problem of human administration. This is to clarify in general what application of philosophy as applied metaphysics amounts to and to show what philosophy in action amounts to.

Before proceeding to perform the major task one need to face the sceptics at least briefly, particularly those who refute the idea of application of metaphysics. My concern is to explain a few arguments of sceptics and refute them in order to fix that idea that metaphysics or ontology can and should be applied in several areas related to human life. Metaphysics tries to discover unity through the domains of thought and experience.

At the metaphysical level, for example, there are many (especially four) extensive philosophical schools of thought that relate to education nowadays such as idealism, realism, pragmatism (sometimes termed experientialism), and existentialism. These metaphysical theories are playing a crucial role to take adverse decisions with the help of their applications in a manner called applied metaphysics or ontology. When we search links, books, articles, and materials written or published on refutation of applied metaphysics or possibility of applied metaphysics, we do not get any exclusive work on it. It does not mean that no thinker, in philosophical world has accepted the applicability of metaphysics/ontology, rather only few have cared of its application although philosophers have some idea about application of metaphysics. For the sake of this work, playing much with sceptics' views is wasting time. 
Notwithstanding, there is a major figure, named Tom Gruber, who refutes the relation between scientists work on something like the gene ontology, and metaphysical or ontological work traditionally done by philosophers. Gruber writes: in philosophy, one can talk about ontology as a theory of the nature of existence... in computer and information science, ontology is a technical term denoting an artefact that is designed for a purpose, which is to enable the modelling of knowledge about some domain, real or imagined (2009: 1963).

In contrast, Berry Smith and Bert Klagges state: applied ontology is a branch of applied philosophy using philosophical ideas and methods from ontology in order to contribute to a more adequate presentation of the results of scientific research (2008: 21). Hence, Gruber's skepticism is unfounded because he did not get the mains theme of application, which is not the scientist $/$ mechanics operation.

Leslie Stevenson (1970: 258-267) thought applied philosophy addressed an audience of non-philosophers but it is not a correct idea because in 1970 there were few applied philosophers around to address. Today both philosophers and non-philosophers address to it. Katherine Hawley presented three case studies which are suitable examples of applying metaphysics/ontology beyond core philosophical vista. She presented applied ontology, social ontology, and natural kinds in psychiatry and medicine. She said that database of restaurant or categories of trip advisor need ontological perception to make programs within computer science. Katherine writes: the designers need to adopt or develop an ontology of restaurants; a system of categories which applies to his domain, and which can be used to organize, query, and articulate information about it. Ontologies are used to help represent scientific knowledge (2017: 169). Applied metaphysics has been explored mostly within the analytic tradition. There is the approach of opening up the philosophical toolbox of conceptual resources to perceive what works in the practical world without essentially accepting any practical claims by philosophers about the nature of reality. Such as to see the ways in which an administrator's relation and position in an organization dipped in utter corruption and her relation and position via social being as well as eco-being come to decide on decision making and/or whistle blowing or even downsizing.

\section{Christopher Hodgkinson on Ontology/Metaphysics of Administration}

Recall that our primary concern in this work is presenting metaphysical application in the field of administration. We have considered a few thinkers to show how metaphysics plays an important role to get applied and to solve many problems. Hodgkinson (1996: 9) has clearly mentioned in his book that a rich range of ontologies sort our belief system. Comparatively, these concepts stand straight upon organization and administration which make them worthwhile. Thus, the metaphysical sideways of well-defined philosophy may give the impression that is very distant at first glimpse from the realm of administrative action. However, if only for the reason that religion and ontology share mutual grounds; and yet they are mutually dependent on each other. It can directly be known that this portion of philosophy have emotional bearing on actions nonetheless, in the person of the administration.

Ultimately, a man is a belief system. When we say so, we keep an ontological proposition in our mind. Hodgkinson says that an administrator's action may be a function of his belief formation; on the other hand, the related value compound or the ontological structure is mindful and expressed as insentient, unexamined, and unspoken. Metaphysical theories frequently control the level and scope of an administrator's obligation and constantly outpouring his 
trustworthy and recognized truthfulness (Hodgkinson 2020). So, metaphysics and theory of mind must cross the starting point into any secretor of the whole complex of inspiration, motivation, interests, benefits, values, and virtues. It could be said that the main ontological apprehension for administration lies in the disjunction such as: Are humans not the same to the rest of the animal kingdom in kind, or only in degree? The point working upon this question is a determining factor of administrative philosophy and, in this manner, upon philosophy-in-action.

We have seen before that most of the thinkers have talked about the same question. They all have tried to make it clear whether humans are different from animals or not? And if they are, what are the differentiating and determining factors? Some considered humans as language using animal, some called them thinking and acting beings, and some as natural doers and all (Bassey 2019). In this regard, Hodgkinson has presented some models-of-man.

He accepts that administrators hold models-of-man and these are rulings of man-in-theworld by which they practice their mode of administrative life in organizations. Some questions are of empirical investigations for sociology not philosophy such as whether implicit or explicit they give assurances to worldviews, religious conviction, or beliefs that are associated with administrative success. Whether males or females with solid religious dogmas are unreasonably signified (or understated) in the upper stages of organizational pyramid? But the philosophic connection between metaphysics and value systems usually is adequately apparent that the issue cannot be swiftly terminated as inappropriate, either to administrative philosophy per se or to the exercise of administration and governance. Let us discuss about it in brief. Hodgkinson has worked separately on Administrative Philosophy and showed ontological/metaphysical, epistemological, and axiological applications in the domain of administration as possible and also required. In a defense of applied ontology/metaphysics with reference to administration, we need to discuss the case of administration and the role and importance of administrative theories. For that matter, we need to have a critical analysis of the ways in which the ontology of man impacts the theories of administration.

Models-of-man cannot and need not be disjoint to ecological conception of man (Bassey \& Nwoye 2018). Here, we need to see whether or not moral beings and things, ecological man and man's future generations are correlated to each other. It is important to mentioned that the main ontological concern in administration could be found in the disjunctions explained by Hodgkinson (1996) so that readers can get the questions and answers of the basic ontological queries. Administrator form their way of organizational life with the help of judgments of manin-the-world and it is possible because they possess of models-of-man. Thus, they (administrator) cannot stop themselves being a philosopher-in-action but can control the quality of that philosophy. (1996: 23) Every administrator will be a philosopher-in-action, but their philosophy of administration will vary because their metaphysical conceptions regarding reality of human beings, world, and all, vary.

In the view of Hodgkinson (1996: 69-85), language is the basic administrative tool. Without having a proper language we cannot communicate and thus cannot administer and govern. Running administration is a kind of leading citizen. Sometimes leadership and administration are considered as one and the same activity. While discussing about administration, its nature, its functions, necessity and all we get indulged into metaphysical discussion which falls into the field of applied metaphysics. Hodgkinson admitted that human organizations are collectives whose necessary and sufficient conditions are purposes, men, and techniques. (1996: 48). 
Not a single organization can move without having some aim, human resources, and proper techniques. These are not only sufficient element of any human organization but also necessary. What next? Who governs these purposes? Who makes humans able to perform in an order? Who makes capable human resources to create and use proper tools and techniques to administer society and maintain justice after all? Is there a moral order in the universe? Every administrator should ask and answer these questions. This process will make them philosopherin-action and as far as they get involved into such critical and conceptual discussions they inevitably get involved into metaphysical application in the domain of administration. Understanding the concept of administration is required here. I will throw light on some very important approaches briefly. Here I go:

\section{Classical Approach (1900-1914)}

It is known as the mechanistic approach. Some thinkers have advocated this approach in their own ways. The classical view undertakes that norms of productivity and proficiency is a blend of methods, objectives, and employees which can be responsible for a logical collation of arrangement and function that would describe and establish a scientific administration. Some of them are as follow:

Frederick W. Taylor- Organizations run by workers as machines (automata). Taylor attempted to construct a science of productive effort. His text, the Principles of Scientific Management is a mile-stone in the field of administration and management. He believed in inductive, pragmatic, and empiricist way of doing any specific task. Automata, here, means an automatic machine, or robotic tool which can run by automation and robotics. So the workers, in any organization, are like automata (Locke 1982).

Henri Fayol - Organization is a mechanism that can be engineered and administration being a type can be engineered. Organization is not something that cannot be disturbed or remade; just like a machine it can be given a new form and formation with the help of efficient engineers and those engineers are administrators who are able to shape and de-shape the organization as per their conceptual intelligence. Fayol shares a rationalist logic and a mechanistic view of organization the way Taylor shared. He was a practical administrator and he adopted more deductive, analytical, and taxonomical approach to deal with organizational structure and function. POSDCORB (planning, organizing, staffing, directing, coordinating, record-keeping, and budgeting) is his contribution in administration which is considered as the complete components of administrative process (Locke 1982).

Max Weber - Administration as rational-legal bureaucracy with scientific-technocratic orientation. Weber worked on authority, power, and bureaucracy in order to search for principles of administration which is the initial point to be generated as the classical position. These theories cannot be bounded within the narrow boundaries of administration but for the reason that consistencies must exist between them and the scientific management school of thought which provide support to the classical position (Locke 1982).

All these conceptions about organization and administration presuppose a metaphysic or ontology of man, organization and environment on the whole (eco-community). In the classical approach, human beings are organizational being and this ontological conception about man here derive the functions of men in an organization they belong. It is basic to our contemporary understanding of the so-called scientific administration in view of ultra- automata, chips, super 
computers and robots coming in relation to man, organization, society, humanity, ecocommunity administration.

\section{Humanistic Approach (1920-30)}

This approach is based on the idea that humans are resources. This approach is widely known as human relations or human resources movement in an organization. The idea of humanistic approach emerged not for the rejection of classical approach but for achieving the same end through different means. Some thinkers have accepted this approach too. They are the following:

Mary Parker Follett- Man-machine-administration conflict resolution by virtue of humans as resource and optimal use of potential. Follett discloses the relations between organization members and administration; and between leaders and the led. To Follett, administration of the human system now dominates over the managing body of the technical system. Humanistic approach has a theme of self-actualization. Organizations take account of (within their group) the prospect for self-realization or self-fulfilment of their members. Every member gives his/her complete potentiality to organization in order to meet self-realization. Administrators must know how to use their potentiality optimally (Abraham 2012).

Abraham Maslow-Self-actualization or self-fulfillment. Through human resource use and for quality of work-life. Herzberg \& Mintzberg and Chester Bernard extended Maslow's concept keen on higher stages of hierarchy even though that extension lead was unstated and embedded in the prior work of Bernard and can be drawn from Plato's Republic (Udoudom \& Bassey 2018). They all believe that organizations and firms do and should not exist generally for making profits or render a service but for the availability of opportunities to grow psychologically and attain self-satisfaction. Making profits and rendering services are necessary but should not be sufficient conditions for the existence of any firm or organization working in public sector.

Quality of work-life theory (QWL) supports and demands for improvement in work conditions and work types in organization. If humans are there to achieve their best through an organization, it would be clear that the employees' work conditions must be humanistic and qualitative. Hodgkinson (1996: 35-36) says that these constructing views about manorganization-administration may be stated as X and Y theories. The former resistant to administration by the automata worker and the latter a motivation theory that enable workers to be altruistic and creative by using potential and self-fulfilling. To this, D. McGregor adds that these models-of-man depends on underlying belief systems or worldviews. Man is to be sure that the resource of administration but not the measure of man is premised upon philosophical bases that can sort from divine to the demonic, the ultimate to the ridiculous.

Both perceptions tell us an inevitable ontology of administration conception. You might think how? When we say that human beings are automata workers or resources which organizations achieve their goals through and vice-versa; we give an ultimate judgment over existence and nature of human being which must be considered as ontology of man we discussed herein. 


\section{Neo-Classical View/The Rational Turn (1939-1949)}

Whenever we talk about general nature of administration we go through, surely, two notable thinkers: H. A. Simon and Chester Bernard. They are logical and scientifically good administrative thinkers. We have briefly discussed Bernard's views about administration and ontological assumption in previous section but shall discuss in a new perspective now.

H. A. Simon- Humans in an organization moved by a high level of consciousness of interdependence and high degree of rational direction of behaviour to achieve ends that are commonly acknowledged and expected. He was a declared logical positivist who believed in decision-making process within administration. For Simon, decisions are taken within the rational limits and under reality restrictions. Simon's values are made for real-world determinations supposed to be folks of the organization and they are inappropriate in the same way that an actor is to his role performance, or the driver of a bus to the destination of the bus. Simon got his inspiration from Bernard and was highly influenced by him (Abraham 2012). Chester Bernard's work has a quality of Platonic philosophy and his ideal administrator holds moral attributes in a manner Plato's guardians hold in the Republic.

E. W. Bakke- Social organization (including family) is differentiated and coordinated human activities, unique problem solving while satisfying human needs, interaction with other systems of human activities and resources in its environment (Abraham 2012). Social organizations have many tasks including differing and coordinating human activities, giving solutions to the problems people face in society for satisfying their needs, creating an interaction among various kind of human activities and making sure they place and function as human beings in environment.

T. Greenfield- Greenfield is a supporter of phenomenological theory of organizations as moral orders and claim that organizations are institutional. Institutions are made of individuals and group of people and hence organization is composed of people (Abraham 2012). Generally, administration is considered as a part of social scientific study, but it has a wide impact over philosophy and philosophy-administration discourse is quite compatible with each other.

\section{Organizational Theory}

Human resource, administration, environment, end/goal/purpose collectively shape this theory. Hodgkinson (1996: 44) says that under this interpretation the task of the executive appears to be one of the reconciliations because; social system, where administrator/leader/manager/ works in, is made of two important elements: institution and individuals. Both institution and individuals have a specific characteristic feature that is, institution has role and individual has personality. Social systems provide ambience to performing certain functions in an institution or by individuals according to their role or expectations (for institution) and needs or dispositions (for individual) and finally observe their behaviour into patterned nexus (Abraham 2012). Thus the task of the administrator is to reconcile both for the betterment of social system.

We have seen that every theory is based on ontology of man and organization in the humanistic and classical approaches respectively, with a turn in taking organizations as moral order. Ontology here does not mean that we are doing a representation of easy concepts into ambiguous words but to define what man and organization stand for. Each administrative 
thinker or philosopher has his/her own description of man and organization and they describe these notions as per their own commitments to their philosophies. Is man a real being? Does organization exist physically? The questions regarding existence of organization, institution, man, administration, their relation and many more are discussed under ontology and when we put it into our active lives, they automatically turn into applied ontology/metaphysics. This is how metaphysics/ontology plays its role in administrative philosophy.

Two American authors; D. Terrence and A. Kennedy have written that Managers run institutions; Heroes create them. (1988: 37) It shows that managers are not who create institutions or the ways of running an institution. So who are they? Who create institutions and institutional rules and code of conduct to move it on in a proper manner? Hodgkinson (1996: 27-48) tried to reply such questions and successfully described the differences between management and administration. This can be an important pillar to set out the ontological/metaphysical grounding of administration because we are trying to see the reality or absolute nature of administration and management in the light of Hodgkinson's view. His attempt was to establish some propositions which administrative philosophy is grounded on. Some basic and important propositions should be widely known to the administrator in order to run good governance. Hodgkinson says that philosophy of administration must be concerned with the inquiry and analysis of administrative conceptions, hence, the language of administration. We know that administration seeks its end through organizational means and organization can be handled by anyone, though anyone can be an administrator but not manager. According to Hodgkinson administrators can be good or bad but management carries a positive value in it, thus it should be controlled by skilled and virtuous people only. Since everyone has an undeniable birth right to philosophy so anyone can lead. We should not take leadership and administration as two different entities but one. There is no difference between the two within this framework.

Further he says that the philosopher of administration must know two important things, first; where the values are and second, where the power lies. Human organizations' necessary and sufficient conditions are three: purposes, men, and techniques. We are all either administered or administering from birth till death. The organisational purposes cannot remain static; they are constantly being modulated by events. Administrative actions are being performed in and by organizations. Administrators create, preserve, and destroy organizations as per their requirement. We see that Hodgkinson focus mainly on organizations. He accepts that organizational theory can only pose the problem for administrative philosophy. For that matter the administrative philosophers play role of a physician of organizational culture and sometimes of a pathologist. Hodgkinson closed his book with a wonderful quotation about administration and administrative philosophy which I would love to quote here "Administration is the art of designing events; administrative philosophy is therefore about the very architecture of reality" (1996: 270).

\section{CONCLUSION}

The aim in this paper was to show the application of metaphysics in administration. It may be said that these metaphysical positions are not sufficient and subject to constructive criticism, and there are many defects. But the point here only represents a hand full of western philosophers. It is evidentially demonstrated that metaphysical application in administration 
does make sense because it bears root on the structure and operations of an organizations over time; but many people are not aware of it. If we pay attention to sound theories or metaphysical presuppositions, when applied in the fields of law, governance, administration and so on, we get better results. Thus, the paper agrees that these theories/applications/views might not be appropriate yet; it guides our search for better metaphysical presuppositions which could be better applied in administration. The work is defending this ontology by analysing unique cases of humane administration, that these metaphysical theses, theories, and conceptions are equally important in resolving real life cases.

\section{REFERENCES}

Abraham, T. H. (2012). "The materials of science, the ideas of science, and the poetry of science": Warren McCulloch and Jerry Lettvin. Interdisciplinary Science Reviews, 37(3), 269-286. https://doi.org/10.1179/0308018812Z.00000000021

Bassey, S. A. (2019). "Anthropoholism" as an authentic tool for environmental management. Вісник Харківського національного університету імені ВН Каразіна. Серія «Філософія. Філософські перипетї̈», (60), 71-81.

Bassey, S. A., \& Nwoye, L. (2018). Environmental Ethics: From Philosophy To Movement. Journal «Bulletin Social-Economic and Humanitarian Research», 39.

French, S. \& McKenzie, K. 2012. Thinking outside the Tool boxll European Journal of Analytic Philosophy. Vol. 8, No. 1.

Gruber, T. (2009). Ontology The Encyclopedia of Database Systems. Edited by I. Liu and M. Tamer Ozsu, Springer, USA.

Hodgkinson, C. (1996). Administrative Philosophy: Values and motivations in Administrative Life. Pergamon, UK.

Hodgkinson, T. (2020). Toward a Materialist Ontology of Art. In Music and the Myth of Wholeness. https://doi.org/10.7551/mitpress/10351.003.0014

Katherine H. (2017). Applied Metaphysics, A Companion to the Applied Philosophy, eds. Kasper-Lippert Rasmussen, Kimberley Brownlee, and David Coady, Willey Blackwell, UK.

Locke, E. A. (1982). The Ideas of Frederick W. Taylor: An Evaluation. Academy of Management Review, 7(1), 14-24. https://doi.org/10.5465/amr.1982.4285427

Stevenson, L. (1970). Applied Philosophy, Metaphilosophy. Vol. 1, No. 3, pp. 258-267.

Terrence, D. \& Kennedy, A. (1988). Corporate Cultures. Penguin Publication, London

Udoudom, M. D., \& Bassey, S. A. (2018). Plato and John Rawls on Social Justice. Researchers World, 9(3), 110.

Varzi, A. C. (2011). On Doing Ontology without Metaphysics, Philosophical Perspectives search for ultimate reality. Journal of Consciousness Studies, 26(7-8), 12-36. 
216 Pinisi Discretion Review

Volume 3, Issue 2, March, 2020 Page. 207- 216 